\title{
Auxiliary Feedwater System Risk-Based Inspection Guide for the J. M. Farley Nuclear Power Plant
}

Manuscript Completed: Septemuer 1990

Date Published: October 1990

Prepared by

T. V. Vo, R. Pugh, B. F. Gore, D. G. Harrison

Pacific Northwest Laboratory

Richland, WA 99352

\section{Prepared for}

Division of Radiation Protection and Emergency Preparedness

Office of Nuclear Reactor Regulation

U.S. Nuclear Regulatory Commission

Washington, DC 20555

NRC FIN L1310

\section{MASTER}


This document presents a compilation of auxiliary feedwater (AFW) system failure information which has been screened for risk significance in terms of failure frequency ard degradation of system performance. It is a riskprioritized listing of failure events and their causes that are significant enough to warrant consideration in inspection planning at the the J.M. Farley plant. This information is presented to provide inspectors with increased resources for inspection planning at J.M. Farley.

The risk importance of various component failure modes was identified by analysis of the results of probabilistic risk assessments (PRAs) ror many pressurized water reactors (PWRs). However, the component failure categories identified in PRAs ar rather broad, because the failure data used in the PRAs is an aggregate of many individuals failures having a variety of root causes. In order to help inspectors to focus on specific aspects of component operation, maintenance and design which might cause these failures, an extensive review of component failure information was performed to identify and rank the root causes of these component failures. Both J.M. Farley and industry-wide failure information was analyzed. Failure causes were sorted on the basis of frequency of occurrence and seriousness of consequence, and categorized as common cause failures, human errors, design problems, or component failures.

This information is presented in the body of this document. Section 3.0 provide brief descriptions of these risk-important failure causes, and Section 5.0 presents more extensive discussions, with specific examples and references. The entries in the two sections are cross-referenced.

An abbreviated system walkdown table is presented in Section 3.2 which includes only components identified as risk important. This table lists the system lineup for normal, standby system operation.

This information permits an inspector to conceritrate on components important to the prevention of core damage. However, it is important to note that inspections should not focus exclusively on these components. Othei components which perform essential functions, but which are not included because of high reliability or redundancy, must also be addressed to ensure that degradation does nnt increase their failure probabilities, and hence their risk importances.

\section{DISCLAIMER}

\footnotetext{
This report was prepared as an account of work sponsored by an agency of the United States Government. Neither the United States Government nor any agency thereof, nor any of their employees, makes any warranty, express or implied, or assumes any legal liability or responsibility for the accuracy, completeness, or usefulness of any information, apparatus, product, or process disclosed, or represents that its use would not infringe privately owned rights. Reference herein to any specific commercial product, process, or service by trade name, trademark, manufacturer, or otherwise does not necessarily constitute or imply its endorsement, recommendation, or favoring by the Unted States Government or any agency thereof. The views and opinions of authors expressed herein du not necessarily state or reflect those of the United States Government or any agency thereof.
} 


\section{CONTENTS}

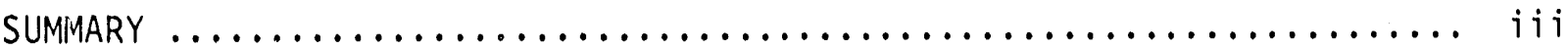

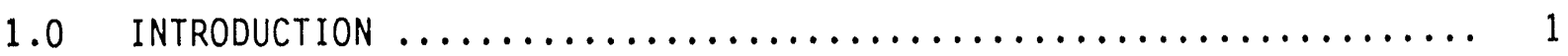

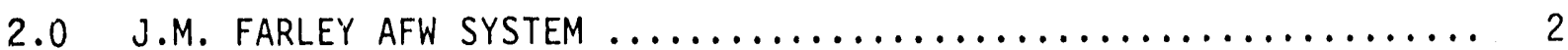

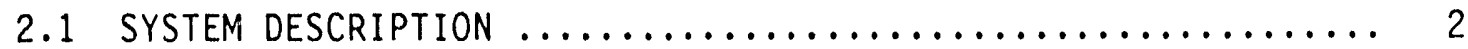

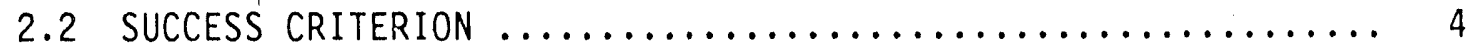

2.3 SYSTEM DEPENDENCIES $\ldots \ldots \ldots \ldots \ldots \ldots \ldots \ldots \ldots \ldots \ldots \ldots \ldots, 4$

2.4 OPERATIONAL CONSTRAINTS $\ldots \ldots \ldots \ldots \ldots \ldots \ldots \ldots \ldots \ldots, 4$

3.0 INSPECTION GUIDANCE FOR THE J.M. FARLEY AFW SYSTEM $\ldots \ldots \ldots \ldots \ldots$..... 5

3.1 RISK IMPORTANT AFW COMPONENTS AND FAILURE MODES $\ldots \ldots \ldots \ldots \ldots$

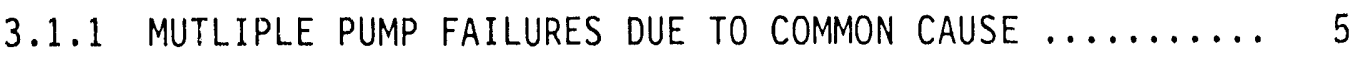

3.1 .2 TURBINE DRIVEN PUMP FAILS TO START OR RUN $\ldots \ldots \ldots \ldots, 6$

3.1.3 MOTOR DRIVEN PUMP A OR B FAILS TO START OR RUN ...... 7

3.1.4 PUMP UNAVAILABLE DUE TO MAINTENANCE

OR SURVEILLANCE $\ldots \ldots \ldots \ldots \ldots \ldots \ldots \ldots \ldots \ldots \ldots \ldots, 7$

3.1.5 AIR OPERATED FLOW CONTROL VALVES FAII. CLOSED $\ldots \ldots \ldots .7$

3.1 .6 MOTOR OPERATED ISOLATION VALVES FAIL CLOSED $\ldots \ldots \ldots . .8$

3.1 .7 MANUAL SUICTIUN OR DISCHARGE VALVES FAIL CLOSED $\ldots \ldots . .8$

3.1.8 LEAKAGE OF HOT FEEDWATER THROUGH CHECK VALVES $\ldots \ldots . .9$

3.2 RISK IMPORTANT AFW SYSTEM WALKDOWN TABLE $\ldots \ldots \ldots \ldots \ldots \ldots . . \ldots$

4.0 GENERIC RISK INSIGHTS FROM PRAs $\ldots \ldots \ldots \ldots \ldots \ldots \ldots \ldots \ldots \ldots \ldots \ldots \ldots \ldots$

4.1 RISK IMPORTANT ACCIDENT SEQUENCES INVOLVING AFW

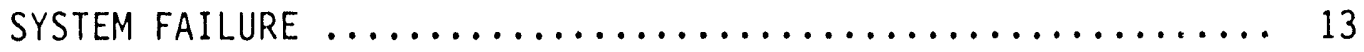

4.2 RISK IMPORTANT COMPONENT FAILURE MODES $\ldots \ldots \ldots \ldots \ldots \ldots \ldots, 14$

5.0 FAILURE MODES DETERMINED FROM OPERATING EXPERIENCE $\ldots \ldots \ldots \ldots \ldots$

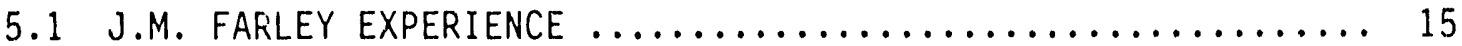




\section{CONTENTS}

(Continued)

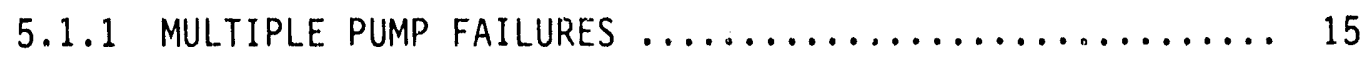

5.1 .2 MOTOR DRIVEN PUMP FAILURES $\ldots \ldots \ldots \ldots \ldots \ldots \ldots \ldots \ldots \ldots$

5.1 .3 TURBINE DRIVEN PUMP FAILURES $\ldots \ldots \ldots \ldots \ldots \ldots \ldots \ldots \ldots$

5.1.4 FLOW CONTROL AND ISOLATION VALVE FAILURES ......... 16

$\because .1 .5$ TURBINE DRIVEN PUMP STEAM SUPPLY, ADMISSION AND CONTROL VALVES ............... 16

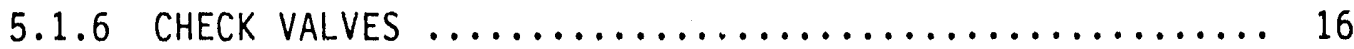

5.1 .7 SERVICE WATER BACKUP SUPPLY VALVES $\ldots \ldots \ldots \ldots \ldots \ldots$

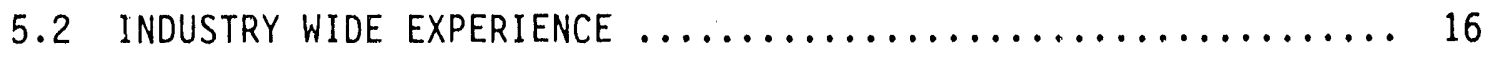

5.2 .1 COMMON CAUSE FAILURES $\ldots \ldots \ldots \ldots \ldots \ldots \ldots \ldots \ldots \ldots \ldots \ldots \ldots \ldots$

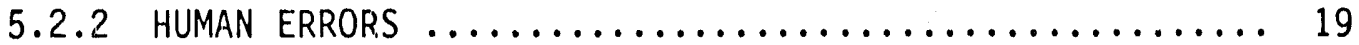

5.2 .3 DESIGN/ENGINEERING PROBLEMS AND ERRORS .......... 20

5.2 .4 COMPONENT FAILURES $\ldots \ldots \ldots \ldots \ldots \ldots \ldots \ldots \ldots \ldots \ldots \ldots \ldots$

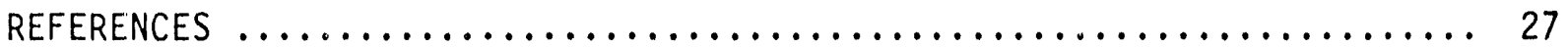




\subsection{INTRODUCTION}

This document is the second of a series providing plant-specific inspection guidance for auxiliary feedwater (AFW) systems at pressurized water reactors (PWRs). This guidance is based on information from probabilistic risk assessments (PRAs) for similar PWRs, industry-wide operating experience with AFW systems, plant-specific AFW system descriptions, and plant-specific operating experience. It is not a detailed inspection plan, but rather a compilation of AFW system failure information which has been screened for risk significance in terms of failure frequency and degradation system performance. The result is a risk-prioritized listing of failure events and the causes that are significant enough to warrant consideration in inspection planning at J.M. Farley.

This inspection guidance is presented in Section 3.0, following a description of the J. M. Farley AFW system in Section 2.0. Section 3.0 identifies the risk important system components by J. M. Farley identification number, followed by brief descriptions of each of the various failure causes of that component. These include specific human errors, design deficiencies, and hardware failures. The discussions also identify where common cause failures have affected multiple, redundant components. These brief discussions identify specific aspects of system or component design, operation, maintenance, ur testing for inspection by observation, records review, training observation, procedures review, or by observation of the implementation of procedures. An AFW system walkdown table identifying risk important components and their 1 ineup for normal, standby system operation is al so provided.

The remainder of the document describes and discusses the information used in compiling this inspection guidance. Section 4.0 describes the risk importance information which has been derived from PRAs and its sources. As review of that section will show, the failure events identified in PRAs are rather broad (e.g., pump fails to start or run, valve fails closed). Section 5.0 addresses the specific failure causes which have been comibined under these broad events.

AitW system operating history was studied to identify the various specific failures which have been aggregated into the PRA failure events. Section 5.1 presents a summary of J. M. Farley failure information, and Section 5.2 presents a review of industry-wide failure information. The industry-wide information was compiled from a variety of NRC sources, including AEOD analyses and reports, information notices, inspection and enforcement sulletins, and generic letters, and from a variety of INPO reports as well. Some Licensee Event Reports and NPRDS ivent descriptions were al so reviewed individually. Finally, information was included from reports of NRC-sponsored studies of the effects of plant aging, which include quantitative analyses of reported AFW s.'stem failures. This industry-wide information was then combined with the plant-specif:c failure information to identify the various root causes of the broad failure events used in PRAs, which are identified in Section 2.0 . 


\subsection{J. M. FARLEY AFW SYSTEM}

This section presents an overview description of the J.M. Farley AFW system, including a simplified schematic system diagram. In addition, the system success criterion, system dependencies, and administrative operational constraints are also presented.

\subsection{System Description}

The AFW system provides feedwater to the steam generators (SG) to allow secondary-side heat removal from the primary system when main feedwater is unavailable. The system is capable of functioning for extended periods, which allows time to restore main feedwater flow or to proceed with an orderly cooldown of the plant to where the residual heat removal (RHR) system can remove decay heat. A simplified schematic diagram of the J.M. Farley AFW system is shown in Figure 2.1.

The system is designed to start up and establish flow automatically. All pumps start on receipt of a steam generator low-low level signal. (The motordriven pumps start on low level in one SG, whereas, two low level signals are required for a turbine-driven pump start.) The motor-driven (MD) pumps start on a trip of major feedwater pumps (MFW) pumps, a safety injection signal, or on a loss of offsite power. The single turbine-driven (TD) pump starts on undervoltage of two of the three reactor coolant (RC) pump buses.

A common header supplies both motor-driven pumps, and a separate line supplies the turbine-driven pump. Isolation valves in these lines are locked open. Power, control, and instrumentation associated with each motor-driven pump are independent from one another. Steam for the turbine-driven pump is supplied by steam generators $B$ and $C$, from a point upstream of the main steam isolation valves, through valve 3226. Each AFW pump is equipped with a continuous recirculation flow system, which prevents pump deadreading.

The discharges of the motor driven pumps are cross connected, and they feed all three steam generators. The turbine-driven pump also feeds all three steam generators, but through seperate lines. Each of these six lines contains a flow-limiting orifice which ensures AFW flow will be provided to intact steam generators if one is depressurized. Each of the lines from the motor driven pumps contains two normally-open isolation motor operated valves (MOVs) 3764A-F. Isolation valves in the lines from the turbine-driven pump are locked open manual valves. Flow control valves $3227 \mathrm{~A}-\mathrm{C}$ and $3228 \mathrm{~A}-\mathrm{C}$ are pneumatic. Each line contains multiple check valves to prevent leakage from the feedwater lines, and the pump suction lines contain relief valves to prevent overpressurization in the case of check valve leakage. 


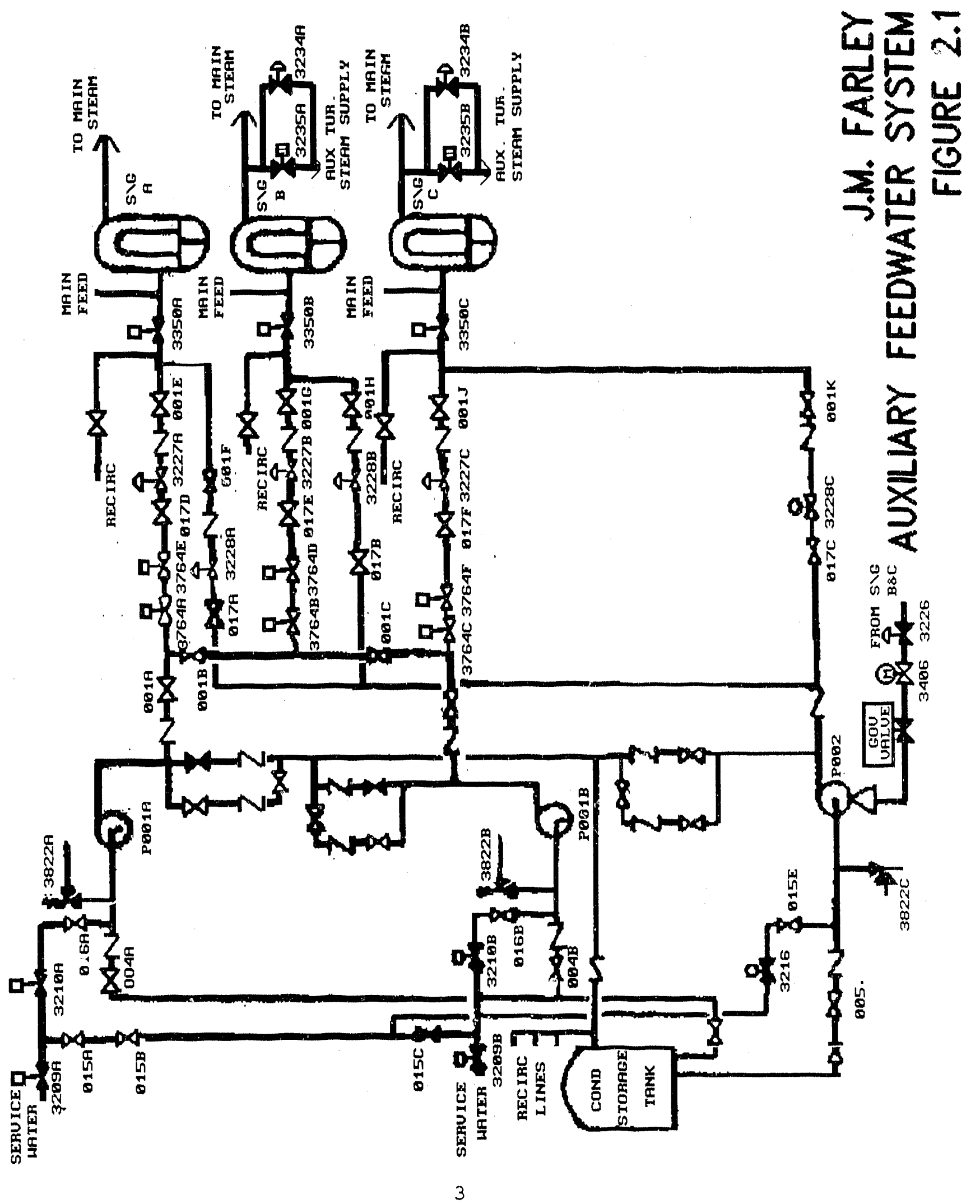


A temperature monitoring system is provided to detect hot feedwater leakage through the system check valves which could cause steam binding of the pumps. Temperatures are monitored at the outlet ard inlet of each AFW pump discharge check valve, and at the inlet of each feed line check valve.

Temperatures are recorded, and a control room alarm is provided to indicate leaks. The pump discharge valves are of the lift type which have proven effective in practically eliminating the problem of check valve leak-by.

The condensate storage tank (CST) is the normal source of water for the AFW System and is required to store sufficient demineralized water to maintain the reactor coolant system (RCS) at hot standby conditions for 9 hours with steam discharge to atmosphere. All tank connections except those required for instrumentation, auxiliary feedwater pump suction, chemical analysis, and tank drainage are located above this minimum level. AFW suction may also be switched to the service water system.

\subsection{Success Criterion}

System success requires the operation of at least one pump supplying rated flow to at least one of the three steam generators.

\subsection{System Dependencies}

The AF' system depends on $A C$ and $D C$ power at various voltage levels for motor operation, valve control, monitor and alarm circuits, and valve/motor control circuits. Instrument Air is required for several pneumatic control valves. Steam availability is required for the turbine-driven pump.

\subsection{Operational Constraints}

When the reactor is critical the J. M. Farley Technical Specifications require that all three AFW pumps and associated flow paths are operable with each motor-driven pump powered from a different vital bus. If one AFW pump becomes inoperable, it must be restored to operable status with in 72 hours or the plant must shut down to hot standby within the next six hours. If two AFW pumps are inoperable, the plant must be shut down to hot standby within six hours. With three AFW pumps inoperable, corrective action to restore at least one pump to operable status must be initiated immediately.

The J. M. Farley Technical Specifications require a nine hour supply of water to be stored in the CST $(150,000$ gallons). With the CST inoperable, the service water systen may serve as backup supply for seven days before plant shutdown is required. 


\subsection{INSPECTION GUIDANCE FOR THE J. M. FARLEY AFW SYSTEM}

In this section the risk important components of the J. M. Farley AFW system are identified, and the important failure modes for these components are briefly described. These failure modes include specific human errors, design deficiencies, and types of hardware failures which have been observed to occur for these components, both at J. M. Farley and at PWRs throughout the nuclear industry. The discussions also identify where common cause failures have affected multiple, redundant components. These brief discussions identify specific aspects of system or component design, operation, maintenance, or testing for observation, records review, training observation, procedures review, or by observation of the implementation of procedures.

Table 3.1 is an abbreviated AFW system walkdown table which identifies riskimportant components. This table 1 ists the system lineup for normal (standby) system operation. Inspection of the identified components addresses essentially all of the risk associated with AFW system operation.

\subsection{Risk Impcricant AFW Components and Failure Modes}

Common cause failures of multiple pumps are the most risk-important failure modes of AFW system components. These are followed in importance by single pump failures, level control valve failures, and individual check valve backleakage failures.

The following sections address each of these failure modes, in decreasing order of risk-importance. They present the important root causes of these component failure modes which have been distilled from historical records. Each item is keyed to discussions in Section 5.2 where additional information on historical events is presented.

\subsubsection{Multiple Pump Failures due to Common Cause}

The following 1 isting summarizes the most impcrtant multiple-pump failure modes identified in Section 5.2.1, Common Cause Failures, and each item is keyed to entries in that section.

- Incorrect operator intervention into automatic system functioniny, including improper manual starting and securing of pumps, has caused failure of a 11 pumps, including overspeed trip on startup, and inability to restart prematurely secured pumps. CC1.

- Valve mispositioning has caused failure of all pumps. Pump suction, steam supply, and instrument isolation valves have been involved. CC2.

- Steam binding has caused failure of multiple pumps. This resulted from leakage of hot feedwater past check valves into a common discharge header, with several valves involved including a motor- 
operated discharge valve. (See item 3.1 .8 below.) CC10. Multiplepump steam binding has also resulted from improper valve lineups, and from running a pump deadheaded. CC3.

- Pump control circuit deficiencies or design modification errors have caused failures of multiple pumps to auto start, spurious pump trips during operation, and failures to restart after pump shutdown. CC4. Incorrect setpoints and control circuit calibrations have also prevented proper operation of multiple pumps. CC5.

- Loss of a vital power bus has failed both the turbine-driven and one motor-driven pump due to loss of control power to steam admission valves or to turbine controls, and to motor controls powered fiom the same bus. CC6.

- Simultaneous startup of multiple pumps has caused oscillations of pump suction pressure causing multiple-pump trips on low suction pressure, despite the existence of adequate static net positive suction head (NPSH). CC7. Design reviews have identified inadequately sized suction piping which could have yielded insufficient NPSH to support operation of more than one pump. CC8.

\subsubsection{Turbine Driven Pump Fails to Start or Run}

- Improperly adjusted and inadequately maintained turbine governors have caused pump failures. HE2. Problems include worn or loosened nuts, set screws, linkages or cable connections, oil leaks and/or contamination, and electrical failures of resistors, transistors, diodes and circuit cards, and erroneous grounds and connections. CF5.

- Terry turbines with Woodward Model EG governors have been found to overspeed trip if full steam flow is allowed on startup. Sensitivity can be reduced if a startup steam bypass valve is sequenced to open first. DE1.

- Condensate slugs in steam lines have caused turbine overspeed trip on startup. Tests repeated right after such a trip may fail to indicate the problem due to warming and clearing of the steam lines.

Surveillance should exercise all steam supply connections. DE2.

- Trip and throttle valve (TTV) problems (FCV-157) which have failed the turbine driven pump include physically bumping it, failure to reset it following testing, and failures to verify control room indication of reset. HE2. Whether either the overspeed trip or TTV trip can be reset without resetting the other, indication in the control room of TTV position, and unambiguous local indication of an overspeed trip affect the likelihood of these errors. DE3. 
Turbines with Woodward Model PG-PL governors have tripped on overspeed when restarted shortly after shutdown, unless an operator has locally exercised the speed setting knob to drain oil from the governor speed setting cylinder (per procedure). Automatic oil dump valves are now available through Terry. DE4.

\subsubsection{Motor Driven Pump A or B Fails to Start or Run}

- Control circuits used for automatic and manual pump starting are an important cause of motor driven pump failures, as are circuit breaker failures. CF7.

- Mispositioning of handswitches and procedural deficiencies have prevented automatic pump start. HE3.

- Low lubrication oil pressure resulting from reatup due to previous operation has prevented pump restart due to failure to satisfy the protective interlock. DE5.

\subsubsection{Pump Unavailable Due to Maintenance or Surveillance}

- Both scheduled and unscheduled maintenance remove pumps from operability. Surveillance requires operation with an altered lineup, although a pump train may not be declared inoperable during testing. Prompt scheduling and performance of maintenance and surveillance minimize this unavailability.

\subsubsection{Air Operated Flow Control Valves Fail Closed}

TD Pump Trains: HV $-3228 A, B, C$

These normally-open air operated valves (AOVs) control flow to the steam generators. They fail open on loss of Instrument Air.

- Control circuit problems have been a primary cause of failures, both at J. M. Farley and elsewhere. CF9. Valve failures have resulted from blown fuses, failure of control components (such as current/pneumatic convertors), broken or dirty contacts, misaligned or broken limit switches, control power loss, and calibration problems. Degraded operation has also resulted from improper air pressure due to air regulator failure or leaking air lines.

- Out-of-adjustment electrical flow controllers have caused improper valve operation, affecting multiple trains of AFW. CC12.

- Leakage of hot feedwater through check valves has caused thermal binding of flow control MOVs. AOVs may be similarly susceptible. CF2. 
- Multiple flow control valves have been plugged by clams when suction switched automatically to an alternate, untreated source. CC9.

\subsubsection{Motor Operated Isolation Valves Fail Closed}

MD Pump Trains: MOV-3764 A-F Complete SG Isolation: MOV-3350A, B, C

These normally open MOVs isolate flow to the steam generators. They fail as - is on loss of power.

- Common cause failure of MOVs has resulted from failure to use electrical signature tracing equipment to determine proper settings of torque switch and torque switch bypass switches. Failure to calibrate switch settings for high torques necessary under design basis accident conditions has also been involved. CC1l.

- Valve motors have been failed due to lack of, or improper sizing or use of thermal overload protective devices. Bypassing and oversizing should be based on proper engineering for design basis conditions. CF4.

- $\quad$ Out-of-adjustment electrical flow controllers have caused improper discharge valve operation, affecting multiple trains of AFW. CC12.

- Grease trapped in the torque switch spring pack of Limitorque SMB motor operators has caused motor burnout or thermal overload trip by preventing torque switch actuation. CF8.

- Manually reversing the direction of motion of operating MOVs has overloaded the motor circuit. Operating procedures should provide cautions, and circuit designs may prevent reversal before each stroke is finished. DE7.

- Space heaters designed for preoperation storage have been found wired in parallel with valve motors which had not been environmentally qualified with them present. DE7.

\subsubsection{Manual Suction or Discharge Valves Fail Closed}

CST Discharge Valves

TD Pump Trains: Valves V005; V015B, E, V017A, $B, C$; or V001F, $H, J$

MD Pump Trains: Valves V004A, $B ;$ V016A, $B$; V017D, E, $F$; or V001E, G, J

These manual valves are normally locked open. For each train, closure of the first valve listed would block suction from CST. Closure of the second valve would block suction from the service water system. Closure of the third and fourth valves would block all pump discharge except recirculation to the CST. 
- Valve mispositioning has resulted in failures of multiple trains of AFW. CC2. It has also been the dominant cause of problems identified during operational readiness inspections. HE1. Events have occurred most often during maintenance, calibration, or system modifications. Important causes of mispositioning include:

- Failure to provide complete, cl sar, and specific procedures for tasks and system restoration

- Failure to promptly revise and validate procedures, training, and diagrams following system modifications

- Faifure to complete all steps in a prucedure

- Failure to adequately review uncompleted procedural steps after task completion

- Failure to verify support functions after restoration

- Failure to adhere scrupulously to administrative procedures regarding tagging, control and tracking of valve operations

- Failure to log the manipulation of sealed valves

- Failure to follow sood practices of written task assignment and feedback of task completion information

- Failure to provide easily read system drawings, legible valve labels corresponding to drawings and procedures, and labeled indications of local valve position

\subsubsection{Leakage of Hot Feedwater through Check Valves:}

At MFW Connections: MOV 3350A, B, C

Discharge of Pumps $A, B ;$ TD Pump: Valves V002A, B; V003

MD Pump Trains: VOO2C,E, G

TD Pump Trains: V002D,F,H

- Leakage of hot feedwater through several check valves in series has caused steam binding of multiple pumps. Leakage through a closed level control valve in series with check valves has also occurrej, as would be required for leakage to reach the motor driven pumps $A$ and $\mathrm{B} . \mathrm{CCl}$.

- Slow leakage past the final check valve of a series may not force upstream check valves closed, allowing leakage past each of them in turn. Piping orientation and valve design are important factors in achieving true series protection. CFl.

\subsection{Risk Inportant AFW System Walkdown Table}

Table 3.1 presents an AFW system walkdown table including only components identified as risk important. This information allows inspectors to concentrate their efforts on components important to prevention of core damage. However, it is essential to note that inspections should not focus exc?usively on these components. Other components which perform essential functions, but which are absent from this table because of high reliability or redundancy, must also be addressed to ensure that their risk importances are not increased. Examples include the (open) steam lead isolation valves upstream of 3226, and an adequate water level in the CST. 
TABLE 3.1. Risk Important Walkdown Table for J.M. Farley AFW System Components

\begin{tabular}{|c|c|c|c|}
\hline Component \# & Component Name & $\begin{array}{l}\text { Required } \\
\text { Position } \\
\end{array}$ & $\begin{array}{c}\text { Actual } \\
\text { Position } \\
\end{array}$ \\
\hline \multicolumn{4}{|c|}{ Electrical } \\
\hline A & Motor-Driven Pump & $\begin{array}{l}\text { Racked In/ } \\
\text { Closed }\end{array}$ & \\
\hline B & Motor-Driven Pump & $\begin{array}{l}\text { Racked In/ } \\
\text { Closed }\end{array}$ & \\
\hline \multicolumn{4}{|c|}{ Valve } \\
\hline$\vee 501$ & CST Outlet Valve & Locked Open & \\
\hline V502 & CST Outlet Valve & Locked Open & \\
\hline V001 A & MDP A Discharge Valve & Locked Open & \\
\hline V001 B & MDP Cross Connect Valve & Locked Open & \\
\hline V001 C & MDP Cross Connect Valve & Locked Open & \\
\hline V001 D & MDP B Discharge Valve & Locked Open & \\
\hline V001 E & AFW Isolation Valve & Locked Open & \\
\hline V001 F & AFW Isolation Valve & Locked Open & \\
\hline V001 G & AFW Isolation Valve & Locked Open & \\
\hline V001 H & AFW Isolation Valve & Locked Open & \\
\hline V001 1 & AFW Isolation Valve & Locked Open & \\
\hline V001 K & AFW Isolation Valve & Locked Open & \\
\hline V002 & TDP Recirculation Valve & Locked Open & \\
\hline V002 A & TDP Main Stream Supply Valve & Locked Open & \\
\hline V002 B & TDP Main Strear. Supply Valve & Locked Open & \\
\hline V005 & TDP Suction Valve & Locked Open & \\
\hline V006 & MDP Recirculation Valve & Locked Open & \\
\hline V004 A & MDP A Suction Valve & Locked Open & \\
\hline
\end{tabular}


TABLE 3.1. Risk Important Walkdown Table for J.M. Farley AFW System Components (Continued)

\begin{tabular}{|c|c|c|}
\hline V004 B & MDP B Suction Valve & Locked \\
\hline V008 & MDP Recirculation Valve & Locked \\
\hline V010 & TDP Recirculation Valve & Locked \\
\hline V0015 A & TDP Service water Suction $V_{a}$ ? ve & Lockeú \\
\hline V0015 B & TDP Service Water Suction Valve & Locked \\
\hline V0015 E & TDP Service Water Suction Valve & Locked \\
\hline V0016 A & MDP Service Water Suction Valve & Locked \\
\hline V0016 B & MDP Service Water Suction Valve & Locked \\
\hline V017 A & AFW Isolation Varve & Locked \\
\hline V017 B & AFW Isolation Valve & Locked \\
\hline V017 C & AFW Isolation Valve & Locked \\
\hline V017 D & AFW Isolation Valve & Locked \\
\hline V017E & AFW Isolation Valve & Locked \\
\hline V107 F & Aiw Isolation Valve & Locked \\
\hline V0019 A & MDP Recirculation Valve & Locked \\
\hline V0019 B & MOP Recirculation Valve & Locked \\
\hline $3764 \mathrm{~A}$ & $\begin{array}{l}\text { MDP to } S / G \\
\text { Isolation Valve }\end{array}$ & Open \\
\hline $3764 B$ & $\begin{array}{l}\text { MDP to } S / G \\
\text { Isolation Valve }\end{array}$ & Open \\
\hline $3764 \mathrm{C}$ & $\begin{array}{l}\text { MDP to } S / G \\
\text { Isolation Valve }\end{array}$ & Open \\
\hline $3764 \mathrm{D}$ & $\begin{array}{l}\text { MDP to } S / G \\
\text { Isolation Valve }\end{array}$ & Open \\
\hline $3764 E$ & $\begin{array}{l}M D P \text { to } S / G \\
\text { Isolation Valve }\end{array}$ & Open \\
\hline
\end{tabular}


TABLE 3.1. Risk Important k'alkdown Table for

J.M. Farley AFW System Components (Continued)

\begin{tabular}{|c|c|c|}
\hline $3764 \mathrm{~F}$ & $\begin{array}{l}\text { MDP to } S / G \\
\text { Isolation Valve }\end{array}$ & Open \\
\hline $3227 \mathrm{~A}$ & $\begin{array}{l}\text { MDP Flow } \\
\text { Control valve }\end{array}$ & Open \\
\hline $3227 \mathrm{~B}$ & $\begin{array}{l}\text { MDF Flow } \\
\text { Control Valve }\end{array}$ & Open \\
\hline $3227 \mathrm{C}$ & $\begin{array}{l}\text { MDP Flow } \\
\text { Control Valve }\end{array}$ & Open \\
\hline $3228 \mathrm{~A}$ & $\begin{array}{l}\text { TDP Flow } \\
\text { Control Vallve }\end{array}$ & Open \\
\hline $3228 \mathrm{~B}$ & $\begin{array}{l}\text { TDP Flow } \\
\text { Control Valve }\end{array}$ & Open \\
\hline $3228 \mathrm{C}$ & $\begin{array}{l}\text { TDP Flow } \\
\text { Control Valve }\end{array}$ & Open \\
\hline $3235 \mathrm{~A}$ & TDP Steam Supply Valve & Open \\
\hline $3235 \mathrm{~B}$ & TDP Steam Supply Valve & Open \\
\hline 3226 & TDP Steam Admission Valve & Closed \\
\hline 3406 & $\begin{array}{l}\text { TDP Throttle-Trip Valve } \\
\text { Supply Valves }\end{array}$ & Open \\
\hline $3209 \mathrm{~A}$ & $\begin{array}{l}\text { Service Water } \\
\text { Supply Valves }\end{array}$ & Closed \\
\hline $3209 \mathrm{~B}$ & $\begin{array}{l}\text { Service Water } \\
\text { Supply Valves }\end{array}$ & Closed \\
\hline $3210 \mathrm{~A}$ & $\begin{array}{l}\text { Service Water } \\
\text { Supply Valves }\end{array}$ & Closed \\
\hline $3210 \mathrm{~B}$ & $\begin{array}{l}\text { Service Water } \\
\text { Supply Valves }\end{array}$ & Closed \\
\hline 3216 & Service Water Supply Valve & Closed \\
\hline $3350 \mathrm{~A}$ & Piping Upstream of Check Valve & nool \\
\hline $3350 \mathrm{~B}$ & Piping Upstream of Check. Valve & 8001 \\
\hline $3350 \mathrm{C}$ & Piping Upstream of Check Valve & $\mathrm{CoO}$ \\
\hline
\end{tabular}




\subsection{GENERIC RISK INSIGHTS FROM PRAS}

PRAs for 13 PWRs were analyzed to identify risk-important accident sequences involving loss of AFW, and to identify and risk-prioritize the component failure modes involved. The results of this analysis are described in this section. They are consistent with results reported by INEL and BNL (Gregg et al 1988, and Travis et al, 1988).

\subsection{Risk Important Accident Sequences Involving AFW System Failure}

\section{Loss of Power System}

- A loss of offsite power is followed by failure of AFW. Due to 1ack of actuating power, the power operated relief valves (PORVs) cannot be opened preventing adequate feed-and-bleed cooling, and resulting in core damage.

- A station blackout fails all AC power except Vital AC from UC invertors, and all decay heat removal systems except the turbinedriven AFW pump. AFW subsequently fails due to battery depletion or hardware failures, resulting in core damage.

- $\quad A D C$ bus fails, causing a trip and failure of the power conversion system. One AFW motor-driven pump is failed by the bus $10 \mathrm{ss}$, and the turbine-driven pump fails due to loss of turbine or valve control power. AFW is subsequently lost completely due to other failures. Feed-and-bleed cooling fails because PORV control is lost, resulting in core damage.

\section{Transient-Caused Reactor or Turbine Trip}

- A transient-caused trip is followed by a loss of the power conversion system (PCS) and AFW. Feed-and-bleed cooling fails either due to failure of the operator to initiate it, or due to hardware failures, resulting in core damage.

\section{Loss of Main Feedwater}

- A feedwater line break drains the common water source for MFW and AFW. The operators fail to provide feedwater from other sources, and fail to initiate feed-and-bleed cooling, resulting in core damage.

- A loss of main feedwater trips the plant, and AFW fails due to operator error and hardware failures. The operators fail to initiate feed-and-bleed cooling, resulting in core damage. 
Steam Generator Tube Rupture (SGTR)

- A SGTR is followed by failure of AFW. Coolant is lost from the primary until the refueling water storage tank (RWST) is depleted. High pressure injection (HPI) fails since recirculation cannot be established from the empty sump, and core damage results.

\subsection{Risk Important Component Failure Modes}

The generic component failure modes identified from PRA analyses as important to AFW system failure are listed below in decreasing order of risk importarice.

1. Turbine-Driven Pump Failure to Start or Run.

2. Motor-Driven Pump Failure to Start or Run.

3. TDP or MDP Unavailable due to Test or Maintenance.

4. AFW System Valve Failures

- steam admission valves

- trip and throttle valve

- flow control valves

- pump discharge valves

- pump suction valves

- valves in testing or maintenance.

5. Supply/Suction Sources

- condensate storage tank stop valve

- hot well inventory

- suction valves.

In addition to individual hardware, circuit, or instrument failures, each of these failure modes may result from common causes and human errors. Common cause failures of AFW pumps are particularly risk important. Valve failures are somewhat less important due to the multiplicity of steam generators and connection paths. Human errors of greatest risk importance involve: failures to initiate or control system operation when required; failure to restore proper system lineup after maintenance or testing; and failure to switch to alternate sources when required. 


\subsection{FAILURE MODES DETERMINED FROM OPERATING EXPERIENCE}

This section describes the primary root causes of AFW system component failures, as determined from a review of operating histories at J. M. Farley and at other PWRs throughout the nuclear industry. Section 5.1 describes experience at J. M. Farley. Section 5.2 summarizes information compiled from a variety of NRC sources, including AEOD analyses and reports, information notices, inspection and enforcement bulletins, and generic letters, and from a variety of INPO reports as well. Some Licensee Event Reports and NPRDS event descriptions were also reviewed individually. Finally, information was included from reports of NRC-sponsored studies of the effects of plant aging, which include quantitative analysis of AFW system failure reports. This information was used to identify the various root causes expected for the broad PRA-based failure events identified in Section 4.0 , resulting in the inspection guidelines presented in Section 3.0 .

\section{$5.1 \quad$ J.M. Farley Experience}

The AFW system at J. M. Farley had experienced failures of the AFW pumps, pump discharge flow control valves, the turbine steam admission and supply valves, turbine trip and throttle valve, pump discharge isolation valves, service water backup supply valves, ard numerous sysiem check valves. Failure modes include electrical, instrumeritation and control, hardware failures, and human errors.

\subsubsection{Multiple Pump Failures}

In one event, both motor driven pumps failed to start due to a combination of mislabeled and mispositioned switches and open links in the balance of plant and hot shutdown panel cabinets.

\subsubsection{Motor Driven Pump Failures}

There have been four aciditional events since 1977 which involved failure of the motor driven pumps during several modes of operation. Failure modes involved instrumentation and control circuit failures, pump hardware failures, and ruman failures during maintenance activities. Misalignment between pump and motor has resulted in high vibration making a pump inoperable. Improper or inadequate maintenance has resulted in high thrust bearing temperatures requiring pump shutdown and repair.

\subsubsection{Turbine Driven Pump Failures}

More than twenty events since 1977 have resulted in decreased operational readiness of the turbine driven pump. Failure modes involved failures in instrumentation and control circuits, electrical faults, system hardware failures, and human errors. The turbine driven pump has tripped or failed to reach proper speed as a result of clogged lube oil lines, dirty limit swit h contacts, misadjusted speed control settings, shorted relays in the speed 
control circuit, and dirty breaker contacts. Pump aging and wear has resulted in high bearing temperatures and on one occasion, pump seizure. Improper part replacement and inadequate maintenance activities have necessitated pump shutdown and repair.

\subsubsection{Flow Control and Isolation Valve Failures}

More than forty-five events since 1977 have resulted in impaired operational readiness of the air operated flow control and motor operated isolation valves. Principal failure causes were equipment wear, instrumentation and control circuit failures, valve hardware failures, and human errors. Valves have failed to operate properly due to blown fuses, failure of control components (such as I/P convertors), broken or dirty contacts, misaligned or broken limit switches, control power loss, and operator calibration problems. Improper air pressure has caused degraded flow control valve operation in a number of events due: to failure of an air regulator or leaking air line. Human errors have resulted in improper control circuit calibration and limit switch adjustment.

\subsubsection{Turbine Driven Pump Steam Supply Adimission, and Control Valves}

More than thirty events since 1977 have resulted in degraded operation of steam isolation steam flow control valves. Failure types included failures due to aging. Deterioration of system hardware resulted in many occurrrences of valve binding, resulting in tripping of overload devices. Flow control valve seats were found to be steam cut, and isolation valves were found to be steam cut, and isolation valves were found to leak due to cut or worn seats. Dirty, worn, or misaligned limit switch contacts have prevented proper valve operation. Improper air pressure resulting from a failed regulator or air line leak has caused failures. Misaligned or out of calibration control circuits and limit switches have resulted in a degraded operational condition. Improper painting has plugged air exhaust ports preventing full stroking of a vaive.

\section{1 .6 Check Valves}

More than forty events of check valve failure have occurred since 1977 . In all but a few cases, normal wear and aging was cited as the failure mode, resulting in leakage.

\subsubsection{Service Water Backup Supply Valves}

Five events have resulted in improper operation of the Service Water backup supply valves due to system wear and aging. In each case, the build up of mud and clams in the service water lines caused improper valve stroking.

\subsection{Industry Wide Experience}

Human errors, design/engineering problems and errors, and component failures are the primary root causes of AFW System failures identified in a review of industry wide system operating history. Common cause failures, 
which disable more than one train of this operationally redundant system, are highly risk significant, and can result from all of these causes.

This section identifies important common cause failure modes, and then provides a broader discussion of the single failure effects of human errors, design/engineering problems and errors, and component failures. Paragraphs presenting details of these failure modes are coded (e.g., CC1) and crossreferenced by inspection items in Section 3.0 .

\subsubsection{Common Cause Failures}

The dominant cause of AFW system multiple-train failures has been human error. Design/engineering errors and component failures have been less frequent, but nevartheless significant, causes of muitiple trón failures.

CC1. Huinan error in the form of incorrect operator intervention into automatic AFW system functioning during transients resulted in the temporary loss of all safety-grade AFW pumps during events at Davis Besse (NUREG-1154, 1985) and Trojan (AEOD/T416, 1983). In the Davis Besse event, improper manual initiation of the steam and feedwater rupture control system (SFRCS) led to overspeed tripping of both turbine-driven AFW pumps, probably due to the introduction of condensate into the AFW turbines from the lonc, unheated steam supply lines. (The system had never been tested with the abnormal, crossconnected steam supply lineup which resulted.) In the Trojan event the operator incorrectly stopped both AFW pumps due to misinterpretation of MFW pump speed indication. The diesel driven pump would not restart due to a protective feature requiring complete shutdown, and the turbine-driven pump tripped on overspeed, requiring local reset of the trip and throttle valve. In cases where manual intervention is required during the early stages of a transient, training should emphasize that actions should be performed methodically and deliberately to guard against such errors.

CC2. Valve mispositioning has accounted for a significant fraction of the human errors failing multiple trains of AFW. This includes closure of normally open suction valves or steam supply valves, and of isolation valves to sensors having control functions. Incorrect handswitch positioning and inadequate temporary wiring changes have also prevented automatic starts of multiple pumps. Factors identified in studies of mispositioning errors include failure to add newly installed valves to valve checklists, weak administrative control of tagging, restoration, independent verification, and locked valve logging, and inadequate adherence to procedures. Illegible or confusing local valve labeling, and insufficient training in the determination of valve position may cause or mask mispositioning, and surveillance which does not exercise complete system functioning may not reveal mispositionings.

CC3. At ANO-2, both AFW pumps lost suction due to steam binding when they were 1 ined up to both the CST and the hot startup/blowdown demineralizer 
effluent (AEOD/C404, 1984). At Zion-1 steam created by running the turbinedriven pump deadheaded for one minute caused trip of a motor-driven pump sharing the same inlet header, as well as damage to the turbine-driven pump (Region 3 Morning Report, 1/17/90). Both events were caused by procedural inadequacies.

CC4. Design/engineering errors have accounted for a smaller, but significant fraction of common cause failures. Problems with control circuit design modifications at Farley defeated AFW pump auto-start cn loss of main feedwater. At Zion-2, restart of both motor driven pumps was b?ocked by circuit failure to deenergize when the pumps had been tripped with an automatic start signal present (IN 82-01, 1982). In addition, AFW control circuit design reviews at Salem and Indian Point have identified designs where failures of a single component could have failed all or multiple pumps (IN 87 $34,1987)$.

Cc5. Incorrect setpoints and coritrol circuit settings resulting from analysis errors and failures io uprlate procedures have also prevented pump start and caused pumps to trip spuriously. Errors of this type may remain undetected despite surveillance testing, unless surveillance tests model all types of system initiation and operating conditions. A greater fraction of instrumentation and control circuit problems has been identified during actual system operation (as upposed to surveillance testing) than for other types of failures.

CC6. On two occasions at a foreign plant, failure of a balance-of-plant inverter caused failure of two AFW pumps. In addition to loss of the motor driven pump whose auxiliary start relay was powered by the invertor, the turbine driven pump tripped on overspeed because the governor valve opened, allowing full steam flow to the turbine. This illustrates the importance of assessing the effects of failures of balance of plant equipment which supports the operation of critical components. The instrument air system is another example of such a system.

CC7. Multiple AFW pump trips have occurred at Millstone-3, Cook-1, Trojan and $\bar{Z}$ ion-2 (IN 87-53, 1987) caused by brief, low pressure oscillations of suction pressure during pump startup. These oscillations occurred despite the availability of adequate static NPSH. Corrective actions taken include: extending the time delay associated with the low pressure trip, removing the trip, and replacing the trip with an alarm and operator action.

CC8. Design errors discovered during AFW system reanalys is at the Robinson plant (IN 89-30, 1989) and at Millstone-1 resulted in the supply header from the CST being too small to provide adequate NPSH to the pumps if more than one of the three pumps were operating at rated flow conditions. This could lead to multiple pump failure due to cavitation. Subsequent reviews at Robinson identified a loss of feedwater transient in which inadequate NPSH and flows less than design values had occurred, but which were not recognized at the time. Event analysis and equipment trending, as well as surveillance testing which duplicates service conditions as much as is practical, can help identify such design errors. 
CC9. Asiatic clams caused failure of two AFW flow control valves at Catawba2 when low suction pressure caused by starting of a motor-driven pump caused suction source realignment to the Nuclear Service Water system. Pipes had not been routinely treated to inhibit clam growth, nor regularly monitored to detect their presence, and no strainers were installed. The need for surveitlance which exercises alternative system operational modes, as well as complete system functioning, is emphasized by this event. Spurious suction switchover has also occurred at Callaway and at McGuire, although no failures resulted.

CC10. Common cause failures have alsu been caused by component failures (AEOD/C404, 1984). At Surry-2, both the turbine driven pump and one motor driven pump were declared inoperable due to steam binding caused by backleakage of hot water through multiple check valves. At Robinson-2 both motor driven pumps were found to be hot, and both motor and steam driven pumps were found to be inoperable at different times. Backleakage at Robinson-2 passed through closed motor-operated isclation valves in addition to multiple check valves. At Farley, both motor and turbine driven pump casings were found hot, although the pumps were not declared inoperable. In addition to multi-train failures, numerous incidents of single train failures have occurred, resulting in the designation of "steam Binding of Auxiliary Feedwater Pumps" as Generic Issue 93. This generic issue was resolved by Generic Letter 88-03 (Miraglia, 1988), which required 1 icensees to monitor AFW piping temperatures each shift, and to maintain procedures for recognizing steam binding and for restoring system operability.

CC11. Common cause failures have also failed motor operated valves. During the total loss of feedwater event at Davis Besse, the normally-open AFW isolation valves failed to open after they were inadvertently closed. The failure was due to improper setting of the torque switch bypass switch, which prevents motor trip on the high torque required to unseat a closed valve. Previous problems with these valves had been addressed by increasing the torque switch trip setpoint - a fix which failed during the event due to the higher torque required due to high differential pressure across the valve. Similar common mode failures of MOVs have also occurred in other systems, resulting in issuance of Generic Letter 89-10, "Safety Related Motor-Operated Valve Testing and Surveillance (Partlow, 1989)." This generic letter requires licensees to develop and implemeni a program to provide for the testing, inspection and maintenance of all safety-related MOVs to provide assurance that they will function when subjected to design basis conditions.

CC12. Other component failures have also resulted in AFW multi-train failures. These include out-of-adjustment electrical flow controllers resulting in improper discharge valve operation, and a failure of oil cooler cooling water supply valves to open due to silt accumulation.

\subsubsection{Human Errors}

HE1. The overwhelmingly dominant cause of problems identified during a series of operational readiness evaluations of AFW systems was human performance. The 
majority of these human performance problems resulted from incomplete and incorrect procedures, particularly with respect to valve lineup information. A study of valve mispositioning events involving human error identified failures in administrative control of tagging and logging, procedural compliance and completion of steps, verification of support systems, and inadequate procedures as important. Another study found that valve mispositioning events occurred most often durirg maintenance, calibration, or modification activities. Insufficient training in determining valve position, and in administrative requirements for controlling valve positioning were important causes, as was oral task assignment without task completion feedback.

HE2. Turbine driven pump failures have been caused by human errors in calibrating or adjusting governor speed control, poor governor maintenance, incorrect adjustment of governor valve and overspeed trip linkages, and errors associated with the trip and throttle valve. TTV-associated errors include physically bumping it, failure to restore it to the correct position after testing, and failures to verify control room indication of TTV position following actuation.

HE3. Motor driven pumps have been failed by human errors in mispositioning handswitches, and by procedure deficiencies.

\subsubsection{Design/Engineering Problems and Errors}

DE1. As noted above, the majority of AFW subsystem failures, and the greatest relative system degradation, has been found to result from turbine-driven pump failures. Overspeed trips of Terry TM(a)turbines controlled by Woodward TM(b) governors have been a significant source of these failures (AEOD/C602, 1986). In many cases these overspeed trips have been caused by slow response of a Woodward Model EG governor on startup, at plants where full steam flow is allowed immediately. This oversensitivity has been removed by installing a startup steam bypass valve which opens first, allowing a controlled turbine acceleration and buildup of oil pressure to control the governor valve when full steam flow is admitted.

DE2. Overspeed trips of Terry turbines have been caused by condensate in the steam supply lines. Condensate slows down the turbine, causing the governor valve to open farther, and overspeed results before the governor valve can respond, after the water slug clears. This was determined to be the cause of the loss-of-a11-AFW event at Davis Besse (AEOD/602, 1986), with condensation enhanced due to the long length of the cross-connected steam lines. Repeated tests following a cold-start trip may be successful due to system heat up.

DE3. Turbine trip and throttle valve (TTV) problems are a significant cause of turbine driven pump failures (IN 84-66). In some cases lack of TTV

(a) Torry is a registered trademark of the Terry Corporation, Windsor, CT.

(b) Woodward is a registered trademark of the Woodward Govenor Company, Rockford, IL. 
position indication in the control room prevented recognition of a tripped TTV. In other cases it was possible to reset either the overspeed trip or the TTV without reseting the other. This problem is compounded by the fact that the position of the overspeed trip linkage can be misleacling, and the mechanism may lack labels indicating when it is in the tripped position (AEOD/C602, 1986).

DE4. Startup of turbines with Woodward Mode1 PG-PL governors within 30 minutes of shutdown has resulted in overspeed trips when the speed setting knob was not exercised locally to drain oil from the speed setting cylinder. Speed control is based on startup with an empty cylinder. Problems have involved turbine rotation due to both procedure violations and leaking steam. Terry has marketed two types of dump valves for automatically draining the $0 i]$ after shutdown (AEOD/C602, 1986).

At Calvert Cliffs, a 1987 loss-of-offsite-power event required a quick, cold startup that resulted in turbine trip due to PG-PL governor stability problems. The short-term corrective action was installation of stiffer buffer springs (IN 88-09, 1988). Surveillance had always been preceded by turbine warmup, which illustrates the importance of testing which duplicates service conditions as much as is practical.

DE5. Reduced viscosity of gear box oil heated by prior operation caused failure of a motor driven pump to start due to insufficient lube oil pressure. Lowering the pressure switch setpoint solved the problem, which had not been detected during testing.

DE6. Waterhammer at Palisades resulted in AFW line and hanger damage at both steam generators. The AFW spargers are located at the normal steam generator level, and are frequently covered and uncovered during level fluctuations. Waterhammers in top-feed-ring steam generators resuited in main feedline rupture at Maine Yankee and feedwater pipe cracking at Indian Point-2 (IN 84$32,1984)$.

DE7. Manually reversing the direction of motion of an operating valve has resulted in MOV failures where such loading was not considered in the design $(A E 0 D / C 603,1986)$. Control circuit design may prevent this, requiring stroke completion before reversal.

DE8. At each of the units of the South Texas Project, space heaters provided by the vendor for use in preinstallation storage of MOVs were found to be wired in parallel to the Class $1 E 125 \mathrm{~V}$ DC motors for several AFW valves (IR $50-489 / 89-11 ; 50-499 / 89-11,1989)$. The valves had been environmentally qualifiel', but not with the non-safety-related heaters energized.

\subsubsection{Component Failures}

Generic Issue II.E.6.1, "In Situ Testing of Valves" was divided into four sub-issues (Beckjord, 1989), three of which relate directly to prevention of AFW system component failure. At the request of the NRC, in-situ testing of check valves was addressed by the nuclear industry, resulting in the EPRI 
report, "Application Guidelines for Check Valves in Nuclear Power Plants (Brooks, 1988)." This extensive report provides information on check valve applications, limitations, and inspection techniques. In-situ testing of MOVs was addressed by Generic Letter 89-10, "Safety Related Motor-Operated Valve Testing and Surveillance" (Partlow, 1989) which requires licensees to develop and implement a program for testing, inspection and maintenance of all safetyrelated MOVs. "Thermal Overload Protection for Electric Motors on SafetyRelated Motor-Operated Valves - Generic Issue II.E.6.1 (Rothberg, 1988)" concludes that valve motors should be thermally protected, yet in a way which emphasizes system function over protection of the operator. CF1. The common-cause steam binding effects of check valve leakage were identified in Section 5.2.1, entry CC10. Numerous single-train events provide additional insights into this problem. In some cases leakage of hot MFW past multiple check valves in series has occurred because adequate valve-seating pressure was limited to the valves closest to the steam generators (AEOD/C404, 1984). At Robinson, the pump shutdown procedure was changed to delay closing the MOVs until after the check valves were seated. At Farley, check valves were changed from swing type to lift type. Check valve rework has been done at a number of plants. Different valve designs and manufacturers are involved in this problem, and recurring leakage has been experienced, even after repair and replacement.

CF2. At Robinson, heating of motor operated valves by check valve leakage has caused thermal binding and failure of AFW discharge valves to open on demand. At Davis Besse, high differential pressure across AFW injection valves resulting from check valve leakage has prevented MOV operation (AEOD/C603, 1986).

CF3. Gross check valve leakage at McGuire and Robinson caused overpressurization of the AFW suction piping. At a foreign PWR it resulted in a severe waterhammer event. At Palo Verde-2 the MFW suction piping was overpressurized by check valve leakage from the AFW system (AEOD/C404, 1984). Gross check valve leakage through idle pumps represents a potential diversion of AFW pump flow.

CF4. Roughly one third of AFW system failures have been due to valve operator failures, with about equal failures for MOVs and AOVs. Almost half of the MOV failures were due to motor or switch failures (Casada, 1989). An extensive study of MOV events (AEOD/C603, 1986) indicates continuing inoperability problems caused by: torque switch/limit switch settings, adjustments, or failures; motor burnout; improper sizing or use of thermal overload devices; premature degradation related to inadequate use of protective devices; damage due to misuse (valve throttling, valve operator hammering); mechanical problems (loosened parts, improper assembly); or the torque switch bypass circuit improperly installed or adjusted. The study concluded that current methods and procedures at many plants are not adequate to assure that MOVs will operate when needed under credible accident conditions. Specifically, a surveillance test which the valve passed might result in undetected valve inoperability due to component failure (motor burnout, operator parts failure, stem disc separation) or improper positioning of protective devices (thermal 
overload, torque switch, limit switch). Generic Letter 89-10 (Partlow, 1989) has subsequently required licensees to implement a program ensuring that MOV switch settings are maintained so that the valves will operate under design basis conditions for the life of the plant.

CF5. Component probiens have caused a significant number of turbine driven pump trips (AEOD/C602, 1986). One group of events involved worn tappet nut faces, locse cable connections, loosened set screws, inproperly latched TTVs, and improper assembly. Another involved oil leaks due to component or seal failures, and oil contamination due to poor maintenance activities. Governor oil may not be shared with turbine lubrication oil, resulting in the need for separate oil changes. Electrical component failures included transistor or resistor failures due to moisture intrusion, erroneous grounds and connections, diode failures, and a faulty circuit card.

CF6. Electrohydraulic-operated discharge valves have performed very poorly, and three of the five units using them have removed them due to recurrent failures. Failures included $0 i 1$ leaks, contaminated oil, and hydrautic pump failures.

CF7. Control circuit failures were the dominant source of motor driven AFW pump failures (Casada, 1989). This includes the controls used for automatic and manual starting of the pumps, as opposed to the instrumentation inputs. Most of the remaining problems were due to circuit breaker failures.

CF8. "Hydraulic lockup" of Limitorque TM(c) SMB spring packs has prevented proper spring compression to actuate the MOV torque switch, due to grease trapped in the spring pack. During a surveillance at Trojan, failure of the torque switch to trip the TTV motor resulted in tripping of the thermal overload device, leaving the turbine driven pump inoperable for 40 days until the next surveillance (AEOD/E702, 1987). Problems result from grease changes to EXXON NEBULA TM(d) EP-O grease, one of only two greases considered environmentally qualified by Limitorque. Due to lower viscosity, it slowly migrates from the gear case into the spring pack. Grease changeover at Vermont Yankee affected 40 of the older MOVs of which 32 were safety relaied. Grease relief kits are needed for MOV operators manufactured before 1975. At Limerick, additional grease relief was required for MOVs manufactired since 1975. MOV refurbishment programs may yield other changeovers to EP-O grease.

CF9. For AFW systems using air operated valves, almost half of the system degradation has resulted from failures of the valve controller circuit and its instrument inputs (Casada, 1989). Failures occurred predominantly at a few units using automatic electronic controllers for the flow control valves, with the majority of failures due to electrical hardware. At Turkey Point-3, controller malfunction resulted from water in the Instrument Air system due to maintenance inoperability of the air dryers.

(c) Limitorque is a registered trademark of the Limitorque corporation, Lynchburg, VA.

(d) Nebula is a registed trademark of the Exxon Corporation, Houston, TX. 
CF10. For systems using diesel driven pumps, most of the failures were due to start control and governor speed control circuitry. Half of these occurred on demand, as opposed to during testing (Casada, 1989).

CF11. For systems using AOVs, operability requires the availability of Instrument Air (IA), backup air, or backup nitrogen. However, NRC Maintenance Team Inspections have identifit inadequate testing of check valves isolating the safety-related portion of tile IA system at several utilities (Letter, Roe to Richardson). Generic Letter 88-14 (Miraglia, 1988), requires licensees to verify by test that air-operated safety-related components will perform as expected in accordance with all design-basis events, including a loss of normal IA. 


\subsection{REFERENCES}

Beckjord, E. S. June 30, 1989. Closeout of Generic Issue II.E.6.1, "In Situ Testing of Valves". Letter to V. Ste110, Jr., U.S. Nuclear Regulatory Commission, Washington, DC.

Brooks, B. P. 1988. Application Guidelines for Check Valves in Nuclear Power Plants. NP-5479, Electric Power Research Institute, Palo Alto, CA.

Casada, D. A. 1989. Auxiliary Feedwater System Aging Study. Volume 1. Operating Experience and Current Monitoring Practices. NUREG/CR-5404. U.S. Nuclear Regulatory Commission, Washington, DC.

Gregg, R. E. and R. E. Wright, 1988. Appendix Review for Dominant Generic Contributors. BLB-31-88. Idaho National Engineering Laboratory, Idaho Falls, Idaho.

Miraglia, F. J. February 17, 1988. Resolution of Generic Safety Issue 93 , "Steam Binding of Auxiliary Feedwater Pumps" (Generic Letter 88-03). U.S. Nuclear Regulatory Commission, Wáshington, DC.

Miraglia, F. J. August 8, 1988. Instrument Air Supply System Problems Affecting Safety-Related Equipment (Generic Letter 88-14). U.S. Nuclear Regulatory Commission, Washington, DC.

Partlow, J. G. June 28, 1989. Safety-Related Motor-Operated Valve Testing and Surveillance (Generic Letter 89-10). U.S. Nuclear Regulatory Commission, Washington, DC.

Rothberg, 0. June 1988. Thermal Overload Protection for Electric Motors on Safety-Related Motor-Operated Valves - Generic Issue II.E.6.1. NUREG-1296. U.S. Nuclear Regulatory Commission, Washington, DC.

Travis, R. and J. Taylor. 1989. Development of Guidance for Generic, Functionally Oriented PRA-Based Team Inspections for BWR P Pants-Identification of Risk-Important Systems, Components and Human Actions. TLR-A-3874-TGA Brookhaven National Laboratory, Upton, New York.

\section{AEOD Reports}

AEOD/C404. W. D. Lanning. July 1984. Steam Binding of Auxiliary Feedwater Pumps. U.S. Nuclear Regulatory Commission, Washington, DC.

AEOD/C602. C. Hsu. August 1986. Operational Experience Involving Turbine Overspeed Trips. U.S. Nuclear ReguTatory Commission, Washington, DC.

AEOD/C603. E. J. Brown. December 1986. A Review of Motor-Operated Valve Performance. U.S. Nuclear Regulatory Commission, Washington, DC.

AEOD/E702. E. J. Brown. March 19, 1987. MOV Failure Due to Hydraul ic Lockup From Excessive Grease in Spring Pack. U.S. Nuclear Regulatory Commission, Washington, DC. 
AEOD/T416. January 22, 1983. LosS of ESF Auxiliary Feedwater Pump Capability at Trojan on January 22, 1983. U.S. Nuclear Regulatory Commission, Washington, DC.

\section{Information Notices}

IN 82-01. January 22, 1982. Auxiliary Feedwater Pump Lockout Resulting from Westinghouse W-2 Switch Circuit Modification. U.S. Nuclear Regulatory Commission, Washington, DC.

IN 84-32. E. L. Jordan. Apri1 18, 1984. Auxiliary Feedwater Sparger and Pipe Hangar Damage. U.S. Nuclear Regulatory Commission, Washington, DC.

IN 84-66. August 17, 1984. Undetected Unavailability of the Turbine-Driven Auxiliary Feedwater Train. U.S. Nuclear Regulatory Commission, Washington, $\overline{D C}$.

IN 87-34. C. E. Rossi. July 24, 1987. Single Failures in Auxiliary Feedwater Systems. U.S. Nuclear Regulatory Commission, Washington, DC.

IN 87-53. C. E. Rossi. October 20, 1987. Auxiliary Feedwater Pump Trips Resulting from Low Suction Pressure. U.S. Nuclear Regulatory Commission, Washington, DC.

IN 88-09. C. E. Rossi. March 18, 1988. Reduced Reliability of Steam-Driven Auxiliary Feedwater Pumps Caused by Instability of Woodward PG-PL Type Governors. U.S. Nuclear Regulatory Commission, Washington, DC.

IN 89-30. R. A. Azua. August 16, 1989. Robinson Unit 2 Inadequate NPSH of Auxiliary Feedwater Pumps. Ailso, Event Notification 16375, August 22, 1989. U.S. Nuclear Regulatory Commission, Washington, DC.

\section{Inspection Report}

IR 50-489/89-11; 50-499/89-11. May 26, 1989. South Texas Project Inspection Report. U.S. Nuclear Regulatory Commission, Washington, DC.

\section{NUREG Report}

NUREG-1154. 1985. Loss of Main and Auxiliary Feedwater Event at the Davis Besse Plant on June 9, 1985. U.S. Nuclear Regulatory Commission, Washington, 


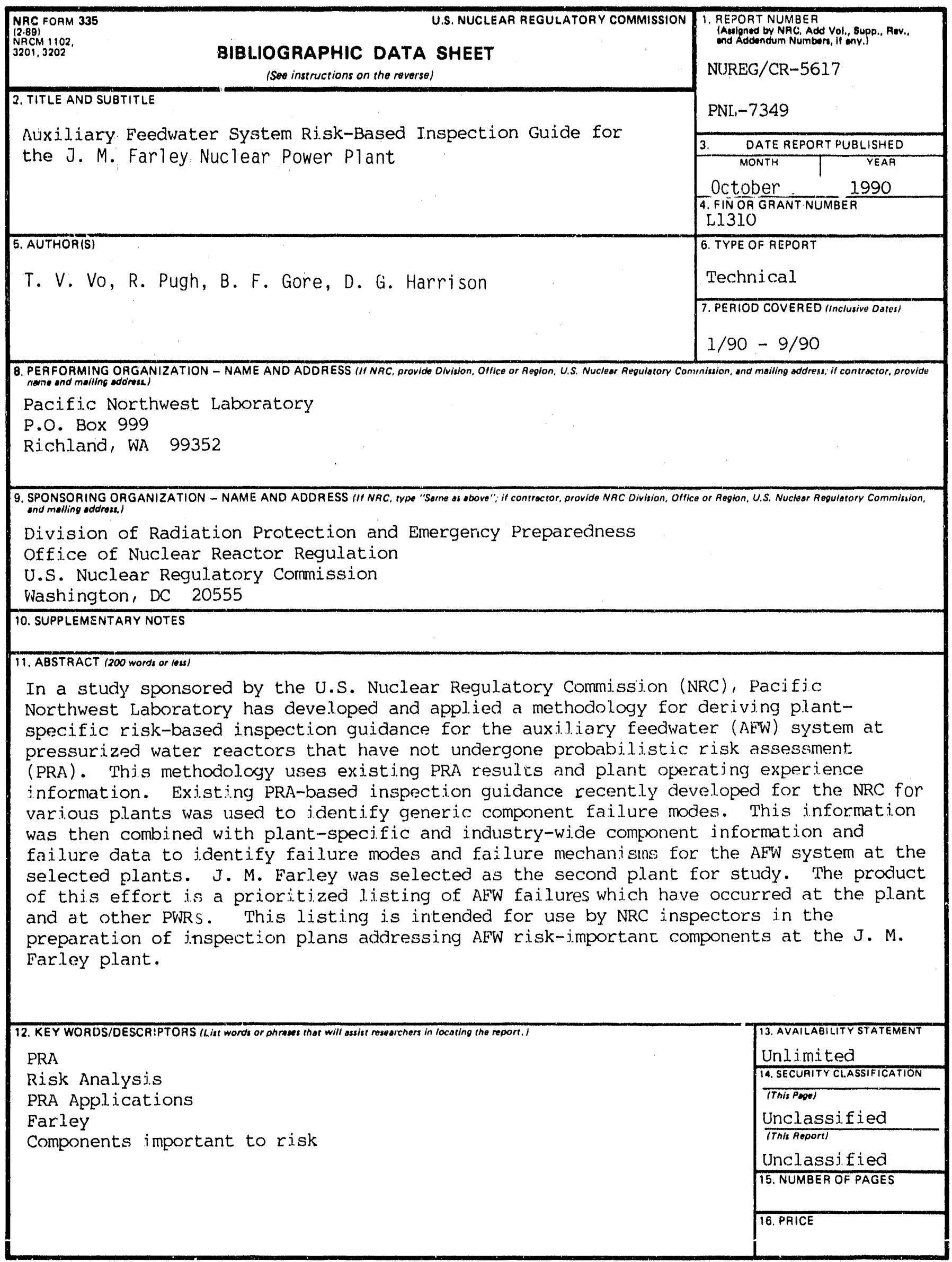



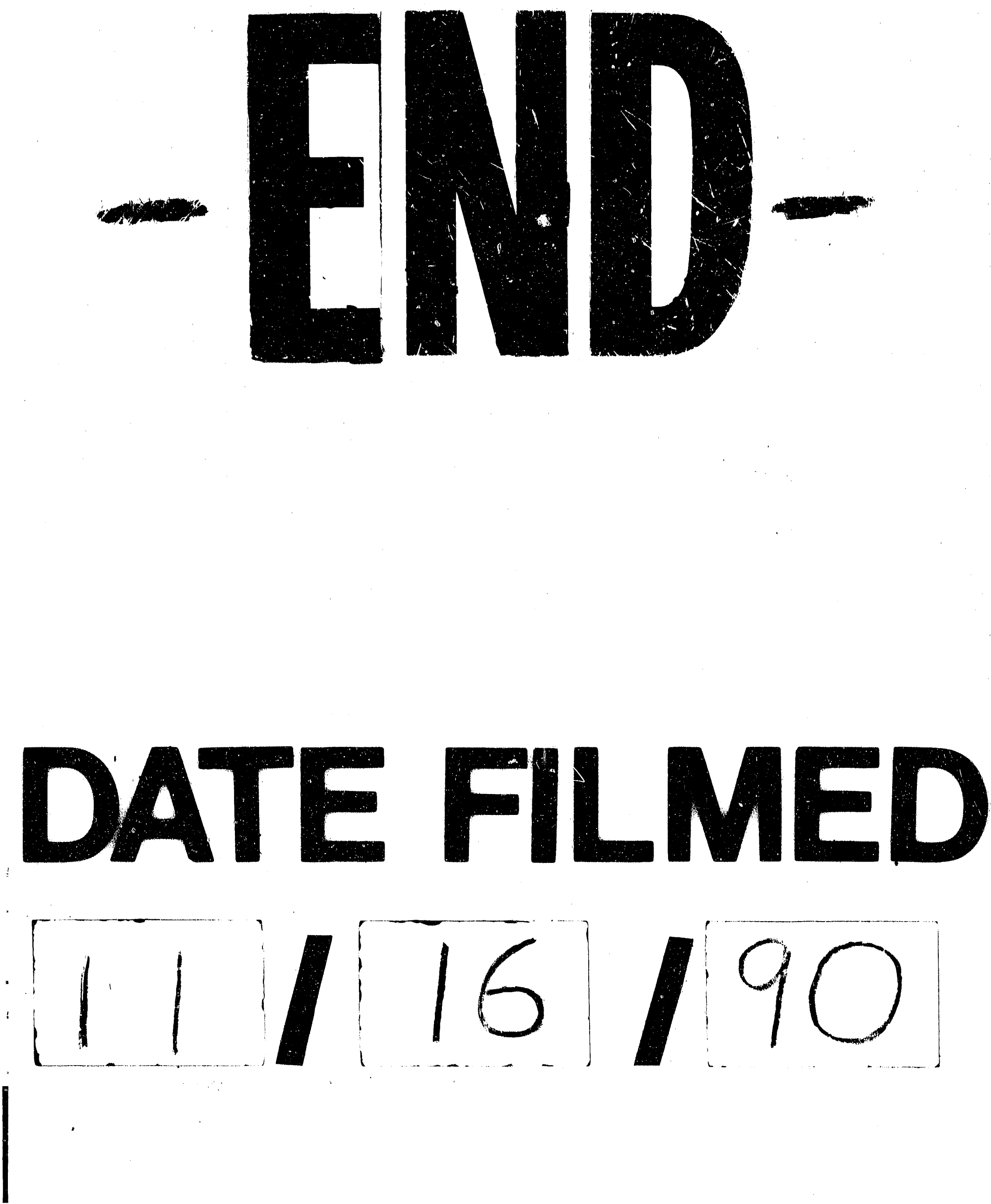
